\title{
Parents Support, Teachers Support, and Intelligence as Predictors of Mathematics Learning Achievement in Class XI of Yogyakarta Senior High Schools
}

\author{
Fitri Ayu Kusumaningrum
}

Master Program of Psychology, Faculty of Psychology, Gadjah Mada University, Yogyakarta, Indonesia; and Department of Psychology, Faculty of Psychology and Social-Cultural Sciences, Islamic University of Indonesia, Yogyakarta, Indonesia Email: fitriayukusumaningrum@uii.ac.id

Asmadi Alsa

Faculty of Psychology, Gadjah Mada University, Yogyakarta, Indonesia; Email: asmalsa@ugm.ac.id

\section{Doi:10.5901/mjss.2016.v7n1p427}

\section{Abstract}

\begin{abstract}
This study aims to analyze and assess the achievement of learning mathematics in terms of high school students based on parental support, teacher support, and intelligence. This study was conducted with a quantitative approach using regression analysis in senior high schools in Yogyakarta. Measurement of mathematics learning achievement was generated from test scores obtained in the final test of Semester II Academic Year of 2013/2014 compiled by teachers. Parental support and teacher support variables were measured using a modified scale. This study was conducted with 145 subjects consisting students from four high schools in Yogyakarta. Schools were selected with a purposive sampling technique with consideration that the school has A-rank in accreditation. Based on the results of data analysis, it is concluded that parental support, teacher support, and intelligence can predict mathematics learning achievement simultanously . In male students, parental support, teacher support, and intelligence can not predict mathematics learning achievement, while in female students, these variable do. The study also reveals that teachers support and intelligence are significantly correlated with mathematics learning achievement, whereas parental support is not.
\end{abstract}

Keywords: Parent Support, Teacher Support, Intelligence, Mathematics Learning Achievement

\section{Introduction}

Indonesian students achievement in mathematics can be categorized as low level compared to their counterparts in other countries. Such low achievement can be seen from the data of PISA (Programme for International Student Assessment), which indicate that the mathematics achievement of students learning Indonesian is ranked second to the lowest score in the survey of Mathematics in 2012. Of 65 countries and regions in the PISA survey, Indonesia students are ranked 64th or only one rank higher than students in Peru (OECD, 2012).

Other data shows that Indonesia ranks 38 of 42 countries on the average score of eighth-grade mathematics learning achievement. Based on TIMSS (Trends in International Mathematics and Science Study) in 2011, provinces in Indonesia are far behind compared to other ASEAN countries such as Singapore, Thailand, and Malaysia (Keswara, 2013).

Based on data analysis and utilization of the National Exam Results 2013-2014 Year Equal SMA (Ministry of Education and Culture \& Tempo, 2014) mentions the data that national absorption majoring in science subjects are as follows: 1) Indonesian (71.20\%); 2) Physics (64.51\%); 3) English (64.33\%); 4) Biology (61.02\%); 5) Mathematics (60.12\%); and 6) Chemicals (59.82\%). Mathematics subjects at high school students majoring in science can be considered low compared to other subjects, although not the lowest.

National Council of Teachers of Mathematics (NCTM) explains that nowadays, anyone who understands and is able to master mathematics will have significantly greater opportunities for building its future (Varol \& Farran, 2006). According to Sembiring, Hadi, \& Dolk (2008) one of the goals of teaching and learning mathematics in Indonesia is to develop reasoning skills and logic skills of students, as well as being one of the methods to develop students' reasoning patterns more systematically. Woolfolk (2007) also reveals that mathematical knowledge is important because it is basic capability that must be mastered by students, in addition to the ability to read and write as basis for other sciences.

Considering achievement in mathematics as important aspect for students success in the future as well as part of 
society's pride, this paper investigates factors potentially predict mathematical achievement. The focus of study is on students of senior high schools in Yogyakarta. The city is chosen for its status as center for exellence in education nationwide. Understanding the nature of predictors of succes factors in mathematics in this city will be considered great window for national improvement.

To ensure the conciseness, this article will be structured as follow: this part deals with introduction to problem of study; next part reviews previous relevant works on the topic; materials and methods are discussed after that; results of study along its discussion will follow and conclusion and suggestion will be generated in the end part of article.

\section{Literature Review}

Some studies suggest that student achievement can be affected by many factors. In general, factors that may affect student achievement can be categorized into two, namely internal and external factors of students or student environment (Suryabrata, 2011). The role of the environment can be seen from the point of view of ecology as described by Brofenbrenner (Santrock, 2010), that environmental factors can affect the learning performance of students. This can be understood by looking at the levels that can affect an individual. Interactions that occur in mikrosistem include individuals with family, school, peers, and neighbors are able to give each other the effect on individual performance.

Based on humanistic approach, students gaining social support will be able to reduce the pressure and the anxiety felt by students when students are cognitively difficult to learn something or to avoid academic tasks. The role of the environment is a source of support to meet the needs of students to anxiety and fear emotionally involving the students (Snowman \& McCown, 2012). Students adolescence is synonymous with peers as many environmental factors that influence, but in the context of education, especially related to student success in school, the support of parents and teachers is the most contributing source of support than the support of friends (Demaray \& Malecki, 2002; Malecki \& Demaray , 2003; Fezer, 2008). Okun, Sandler, and Baumann (in Goldsmith, 2004) revealed that teachers and family support (but not the support of a friend), a buffer negative impact on students of adverse events in the school and encourage a positive impact on positive events in school.

Parental support can make a positive contribution to the achievement of student learning Mathematics (Tocci \& Engelhard, 1991; Lee, Smith, Perry \& Smylie, 1999; Downs, 2006; Chiu, 2010; Harrison, 2011; and Syafaruddin, 2012). Mathematics learning achievement is not because of the support of the teacher. The study by Lee, et al. (1999); Lopez, Ehly, and Garcia-Vazquez (2002); and Chen (2005) revealed that teacher support positively correlated to the achievement of learning Mathematics. Based on the above, social support from parents and teachers are the external factors that can affect students' learning achievement in Mathematics.

The role of intelligence in Mathematics performance becomes very important. Mathematics is a subject that demands the ability of abstraction, the students were introduced to operations that use numbers and symbols to solve a mathematics problem, such as addition and subtraction. Therefore, the intelligence is a factor to support the success of learning mathematics because mathematics covers a fairly complex process of thinking (Woolfolk, 2007). Intelligence as one of the internal factors that can affect the achievement of learning mathematics can be seen from the results of the study Siegler, Duncan, Davis-Kean, Duckworth, Claessens, Engel, Susperreguy, and Chen (2012); Rosal, Jorge, and Sierra (2012); Murayama, Pekrun, Lichtenfeld, and Hofe (2012); and Rustika (2014). Based on the explanation above, it appears that parental support, teacher support, and intelligence is positively correlated to student achievement, particularly the achievement of learning Mathematics.

Mathematics achievement of this study can be seen in the form of figures based on quantitative/scores (Alsa, 2005). Definition of parental support is social support can be provided by a source of social support is one of the parents (House, in House \& Kahn, 1985). According to Tardy (Malecki \& Demaray in 2003), social support parental support is provided by a source of support network, one of the parents. The definition of a teacher is idukungan is social support can be provided by a source of social support is one of the teachers (House, in House \& Kahn, 1985). According to Tardy (Malecki \& Demaray in 2003), social support parental support is provided by a source of support network, one of the teachers. Support teachers by Trickett \& Moos (Mitchell \& DellaMattera in 2010) is something that is believed by the student to the teacher who cares and will provide assistance when students need.

From the explanation above it is clear that many factors can predict students achievements including in mathematics. Among these factors, this study focus on parental support, teacher support, and intelligence as main predictors for students achievement. For this purpose, this study state a hypothesis that the parental support, teacher support, and intelligence can predict students' mathematics learning achievement. 


\section{Materials and Methods}

Research Subjects: This study was conducted on 145 subjects from four accredited high schools, of class XI students majoring in science and aged 16 to 18 years. The subjects were taken with purposive sampling.

Data Measurement Tools: Mathematics learning achievement is measured through test results in mathematics. This study uses data documentation of mathematics raw score learning of class XI science majors at final examination or UAS in Bahasa Indonesia (stands for Ujian Akhir Semester) second six-monthly of academic year 2013/2014. Mathematics learning achievement test is organized by class XI of Science mathematics teacher. The validity of the mathematics achievement test, refers to the logical validity. Logical validity of the assessment is qualitative and assessed by a team of experts (Azwar, 2012).

Parental support and teacher support use the scale as a measurement instrument. The scale of parental and teachers supports are prepared by the researchers with reference to the House \& Kahn (1985) and Malecki \& Demaray (2002) and has been adapted to junior high school students. Parental support scale includes four aspects namely: 1). Emotional, self-esteem indicators include influence, trust, attention, and listening; 2). Appraisal, the indicator includes strengthening, giving feedback, and comparing the social impact; 3) Instrumental, the indicator includes providing assistance, money, assignment, modifying the environment, and taking the time; and 4). Informational, the indicators include providing advice, suggestions, guidance, and information. Parental support scale reliability was 0.898 , while the teacher support was 0,911 . As for intelligence tests, this study uses CFIT (Culture Fair Intelligence Test) scale 3 forms A and B. Its validity is from $0,50-0,70$ and 3, and its reliability is .69 to .85 (Cattell \& Cattell, 1959).

Research Design: This study employs quantitative approach with multiple regression analysis. Multiple regression analysis is aimed to measure the magnitude of the effect between two or more independent variables in this case predictors to the dependent variable represented by achievement in mathematics (Field, 2005). Such analysis was chosen since main idea of this study was to improve mathematical achievement so that identifying best predictors for it is necessarily important and regression has been the best tool for this purpose.

\section{Results}

The data of 145 subjects was collected. 14 of this data could not be used because the students as subjects were absent during collection of data or they filled instrument incompletely. The final data used for further analysis are from 145 subjects. The detail on subjects can be viewed in the following table.

Table 1. Description of Research Subjects

\begin{tabular}{lcccc}
\hline \multirow{2}{*}{ School Name } & \multirow{2}{*}{ School Status } & \multicolumn{3}{c}{ Number of Students } \\
\cline { 3 - 5 } & & Total & Male & Female \\
\hline SMA Negeri 9 & State-Owned & 86 & 34 & 52 \\
SMA UII & Private-Owned & 30 & 19 & 11 \\
SMA Budya Wacana & Private-Owned & 20 & 7 & 13 \\
SMA Gama (Tiga Maret) & Private-Owned & 23 & 9 & 14 \\
\hline TOTAL & & 159 & 69 & 90 \\
\hline
\end{tabular}

Source: Primary Data

The data in the table above indicates that the subejcts have been equally selected from two types of schools: private and state owned as well as form male and female ratio. Characteristics of the subjects in the form of maximum score, minimum score, mean, and standard deviation both empirical and hypothetical statictics are described in the following table.

Table 2. Empirical and Hypothetical Description of Research Data

Source: Primary Data

\begin{tabular}{lcccccccc}
\hline \multirow{2}{*}{ Variables } & \multicolumn{4}{c}{ Hypothetical } & \multicolumn{4}{c}{ Empirical } \\
\cline { 2 - 9 } & Min & Max & Mean & SD & Min & Max & Mean & SD \\
\hline Parents Support & 34 & 136 & 85 & 17 & 76 & 136 & 109,262 & 11,008 \\
Teachers Support & 30 & 120 & 75 & 15 & 30 & 112 & 75,883 & 13,353 \\
Mathematics Achievement & 0 & 100 & 50 & 16,6 & 25 & 89 & 64,191 & 13,871 \\
Intelligence & - & - & 100 & - & 63 & 137 & 102,641 & 16,298 \\
\hline
\end{tabular}


Linearity test is necessary when the correlation between the dependent variable with the independent regression analysis, the correlation is low (Hadi, 2001). The linearity test results in this study are summarized in Table 3 below.

Table 3. Linearity Test Results for Correlation of Each Independent Variables with Mathematics Achievement

\begin{tabular}{lccccc}
\hline \multirow{2}{*}{ Independent Variables } & \multirow{2}{*}{ Dependent Variables } & \multicolumn{3}{c}{ Linearity Test Results } & \multirow{2}{*}{ Conclusion } \\
\cline { 3 - 6 } & & Deviation & $\mathbf{F}$ & $\mathbf{p}$ & \\
\hline Parents Support & & 0,757 & 0,133 & 0,844 (deviation) Linear $(p>0,05)$ \\
Teachers Support & Mathematics Achievement & 1,255 & 3,815 & 0,174 (deviation) & Linear $(p>0,05)$ \\
Intelligence & & 1,103 & 6,101 & 0,015 (linearity) & Linear $(p<0,05)$ \\
\hline
\end{tabular}

\section{Source: Primary Data}

Multicollinearity assumption states that the independent variables should not highly correlated with each other. Myers (in Field, 2005), states that the VIF value of less than 10 showed no symptoms of multicollinearity, while Menard (in Field, 2005) states that the tolerance values below 0.1 indicate the presence of symptoms of serious multicollinearity. The results obtained in this study indicates that multicollinearity tolerance values are $0.998 ; 0.996 ; 0.995$ and VIFs are 1.002; $1.004 ; 1.005$.

This study testes parental support, teacher support, and intelligence can predict mathematics achievement of senior high school students. The results of the analysis using regression showed coefficient correlation of $R=0.262$ and the value of $F=3,460$ with $p=0.018(p<0.05)$. Based on regression analysis that has been performed, $R$ Squared value obtained is 0.069 . This result indicate that mathematics achievement in high school students can be predicted from the variable parental support, teacher support, and intelligence all together by $6.9 \%$.

This research only recomputed to include variables that correlated with learning achievement in mathematics. It aims to increase the accuracy of the data and determine the predictive power of each variable. Based on that, then recomputation is done only by including independent variables or predictors correlated with learning achievement, i.e. teacher support and intelligence.

Based on the analysis performed by including only teacher support variable $(X 1)$ and intelligence $(X 2)$, this study showed the value of $R=0.260$ and $F=5,160$ with $p=p=0.007(p<0.01)$. Regression analysis result shows value of $R$ Square $=0.068$. From the above description, it can be concluded that teacher support and intelligence together can predict mathematics achievement by $6.8 \%$. The regression model in this study can be formulated as follows:

$Y=32,709+0,174 X 1+0,178 X 2$

Additional analysis was conducted involving gender roles in testing the hypothesis. In the case of male students, the results of the analysis using regression analysis showed a correlation coefficient $R=0.243$; value of $F=1,134$ with a value of $p=p=0.344(p>0.05)$. Based on these results, it can be concluded that on the male subjects, parental support, teacher support, and intelligence cannot predict mathematics achievement together.

As for the female students, the result shows value of $R=0.323$; value of $F=3,219$, with $p=0.027(p<0.05)$. Based on these results, it can be conclude that on the female subject, parental support, teacher support, and intelligence can predict mathematics achievement together.

\section{Discussion}

Intelligence is viewed as a factor that may affect the achievement of mathematics as described early in the literature review. The results of this study indicate that intelligence is positively correlated with mathematics achievement. These results are consistent with the findings of earlier studies which explained that the intelligence related to mathematics achievement (Rosal, et al., 2012; Siegler, et.al. 2012; Murayama, et al., 2012; Rustika, 2014). The results of this study also indicate that teacher support was positively correlated with mathematics achievement. This is consistent with previous findings that Lee, et al. (1999); Lopez, et al. (2002); Chen (2005); Fezer (2008); and Sakiz, Pape, and Hoy, 2011, which states that the support of teachers correlated with mathematics achievement.

In the above description, it can be observed from the application of humanistic paradigm in education that the students who met their needs to be appreciated, loved, owned, will reach the self-actualization process as part of the development of student potential. Teachers are able to provide a sense of security, sense of being loved and owned, selfesteem, as well as provide space for students to proceed in developing its potential with reference to the uniqueness of each individual, will give the student self-actualization needs (Lefrancois, 2000). The process of fulfilling the needs of these students can be obtained from the social support provided by parents and teachers as an adult figure around 
students (Malecki \& Demaray, 2003).

The role of social support in the humanistic approach have become important factors in student achievement because involves not only cognitive factors, but also affection or emotion (Lefrancois, 2000; Woolfolk, 2007; Sternberg \& Williams, 2009; and Schunk, 2012), positive social interaction (Parsons, Hinson, \& Brown, 2001; Sternberg \& Williams, 2009; Santrock, 2011), as well as a source of social support to meet the needs of students for achievement (Lefrancois, 2000; Sternberg \& Williams, 2009; Schunk, 2012; and Snowman \& McCown, 2012).

This was confirmed by research Fezer (2008) that states that the form of emotional support for teachers is related to academic achievement, school attendance, student behavior, and school satisfaction. The support of teachers can be manifested in giving award with regard to student behavior at school. Teachers support in the form of emotional support, information, instrumental and award can be a predictor of the academic success (including mathematics) for senior high school students. Teachers who understand when, how, and the impact of this form of support to student will be able to give a positive response to the expected behavior (Fezer, 2008).

Forms of teacher support may include information, awards, instrumental, and emotional. Teachers in the form of emotional support given to students can have a positive influence on mathematics achievement. This can be explained by Buka \& Assoc's (2013) study which describes the study of literature that teachers who have a positive relationship both emotionally and academically as a form of support to students, will encourage student motivation and engagement in learning. This will improve the climate conducive learning, social skills and achievement. Teachers support in the form of information can affect mathematics achievement through their competence. Teachers who have competence in teaching are evaluated positively by students as being able to provide support in the form of information. This support will affect student competence in mathematics as well as their achievement (Park, 2004).

The results showed that parental support cannot predict mathematics achievement in high school students. The support given by parents to students of senior high school is the most important form of support that is felt in all aspects of life. However, parental support is not a form of support which can assist students in their academic success (Fezer, 2008). The support should be attached to students' developmental stages and also internal factors inherent in the student, for example intelligence, aptitude, interest, personality, and so on. This is in line with the opinion of Goldsmith (2004) who states that the form of support provided should be appropriate to the needs of the recipient so it will be meaningful one.

At the teenagers, characteristics of the support from parents to students should be in the form of autonomy and achievement orientation. Parents should be able to explain the reason in consistent and rational ways to make students understand the rules imposed by the process of discussion and their state of adolescent should also be involved. This approach should also be used in making decisions on issues involving self-control adolescents (Shaffer \& Kipp, 2010). This result is also in line with Chen's (2005) findings that show parental support is not a good predictor for learning achievement in mathematics for senior high school students. This result was based on the fact that many teenagers need autonomy and being released from parental influence. They also have strong willingness to be independent and strive for the effort by themselves. For these reasons it is important that parents know whether their children need or not parents help.

Another explanation is the presence of a reactive strategy conducted by parents after knowing low performance of students in school. Or in other words, parental support will be provided only to improve students when they perform poorly in school (Chen, 2005). Parents should pay more attention that their supports are meant to fulfilling the needs of the children so that they can improve their performance. Ulfah's (2012) research results that parental support was not significantly correlated with academic achievement (including mathematics) to adult students. The above opinion is confirmed by the results of the study Hong, Yoo, You, and Wu (2010) that showed that parental support through its involvement by providing reinforcement to the child, has no effect on high school students' mathematics achievement.

The results of research that teenage students receive more social support from peers can be a good explanation for this case. Teenage students will feel comfortable in the classroom and in the school if they receive emotional support from peers (Fezer, 2008) as well as peers who are able to set standards high among other friends (Chen \& Stevenson, 1995). Johnson (2000) clearly point out that acceptance in peer group can improve pro-social behavior in children's life, including academics (Wentzel \& Caldwell, 1997) which in the further development can affect their self-esteem and other social consequences (Guay, Boivin, \& Hodges, 1999). Students gain a lot of information about capabilities to improve through the knowledge shared by others in the group (Schunk, 2012).

Different socio-economic backgrounds can be traced as cause for variety of results among controlled variables. A study by Fan (2012) notes that there is positive influence on the socio-economic background of parents toward increasing student achievement. The relatively same results can also be obtained from Kiamanesh's (2004) and Chen's (2005) studies that indicate students' learning achievement in mathematics can be influenced by family background, including 
educational and instrumental support at home. Siegler, et al. (2012) also mention that educational background and parental income can affect the achievement of students in learning mathematics.

Based on the results of this study, parental support, teacher support, and intelligence cannot predict mathematics achievement in male subjects. However, different results were obtained for female subjects, whose parental support, teacher support, and intelligence can predict their mathematical achievement simultaneously. These results are in line with the Malecki \& Demaray (2002), Demaray \& Malecki (2003), Jackson \& Warnen (in Fezer, 2008), who reported that female students obtain more social support than male.

\section{Conclusion and Suggestion}

Based on the previous analysis and discussion, it can be concluded that: 1) parental support, teacher support, and intelligence can simultaneously predict students' achievement in mathematics in senior high schools; 2) for male students, these factors do not significantly predict achievement while for female groups, these factors do significantly; 3 ) teacher support and intelligence were correlated with mathematical achievement of senior high school students, while parental support itself was not correlated with mathematical achievement of the subjects.

Some suggestions can be derived from this study: firstly, teachers need to maintain and improve the forms of support for students to achieve the best achievement in mathematics. Secondly, teachers need to evaluate the provision of support to students with personal attention to the characteristics of the students. Thirdly, further research in achievement in mathematics among senior high school students are advised to utilize constructs such as peer support. In addition, this study has many limitations so that further research may benefit more by considering the usage of different sampling techniques as well as more subject to enable deeper results in population representation.

\section{Acknowledgments}

The Authors thank Faculty of Psychology, Gadjah Mada University for financial support that make the research possible.

\section{References}

Alsa, A. (2005). Program belajar, jenis kelamin, belajar berdasar regulasi diri dan prestasi belajar Matematika pada pelajar SMA negeri di Yogyakarta [Learning program, sex, self-regulated learning and Mathematics achievment of the state high school students in Yogyakarta]. (Doctoral dissertation). Yogyakarta, Indonesia: Faculty of Psychology, Gadjah Mada University.

Azwar, S. (2012). Reliabilitas dan validitas (Edisi keempat) [Reliability and validity (Fourth edition)]. Yogyakarta: Pustaka Pelajar.

Buka, P., \& Assoc. (2013). Promoting academic achievement through positive relationships. Journal of Educational and Social Research, 3(3). DOI: 10.5901/jesr.2013.v4n3p323

Cattell, T. B., \& Cattell, A. K. S. (1959). Handbook for the culture fair intekkigence test a measure of $g$ scale 3 , forms a and b (high school pupils and adults of superior intelligence. USA: Institute for Personality and Ability Testing.

Chen, C. \& Stevenson, H. W. (1995). Motivation and mathematics achievement: A comparative study of Asian-American, CaucasianAmerican, and East Asian high school students. Child Development, 66(4), 1215-1234. DOI: 10.1111/j.1467-8624.1995.tb00 932.x

Chen, J. J.L. (2005). Relation of academic support from parents, teacher, and peers to Hong Kong adolescents' academic achievement: The mediating role of academic engagament. Genetic, Social, and General Psychology Monographs, 13(2), 77-127. DOI: 10.3200/MONO.131.2.77-127

Chiu, M. M. (2010). Effects of inequality, family, and school on mathematics achievement: Country and student differences. Social Forces, 88(4), 1645-1676. DOI: 10.1353/sof.2010.0019

del Rosal, A. B., Jorge, C. M. H., \& Sierra, M. A. G. (2012). Achievement predictors in a secondary student's sample. Quality \& Quantity, 46(6), 1687-1697. DOI: 10.1007/s11135-011-9547-5.

Demaray, M. K., \& Malecki, C. K. (2002). The relationship between perceived social support and maladjustment for student at risk. Psychology in the School, 39(3), 305-316. DOI: 10.1002/pits.10018

Demaray, M. K., \& Malecki, C. K. (2003). Importance ratings of socially supportive behaviors by children and adolescents. School Psychology Review, 32, 108-131. Retrieved from http://www.nasponline.org/publications/periodicals/spr/volume-32/volume-32issue-1/importance-ratings-of-socially-supportive-behaviors-by-children-and-adolescents.

Downs, P. A. (2006). Student and parent perceptions of academic efficacy, abilities, and support: Their relationships to Najavo American Indian high school student's academic achievement. (Doctoral dissertation). United States: ProQuest Information and Learning Company.

Fan, F. A. (2012). The relationship between the socio-economic status of parents and student's academic achievements in social studies. Research in Education, 87(1), 99-103. DOI: 10.7227/RIE.87.1.8

Fezer, M. (2008). Adolescent social network: Student academic success it relates to source and type of support received. (Doctoral 
dissertation). USA: ProQuest LLC.

Field, A. (2005). Discovering statistics using SPSS for windows. London: Sage.

Goldsmith, D. J. (2004). Communicating social support. USA: Cambridge University Press.

Guay, F., Boivin, M. \& Hodges, E. V. E. (1999). Social comparison processes and academic achievement: the dependence of the development of self-evaluations on friends' performance. Journal of Educational Psychology, 91(3), 564-568. DOI: 10.1037/00220663.91.3.564

Hadi, S. (2001). Isu uji asumsi (Issues in assumption test). Buletin Psikologi, IX(1), 1-7. Retrieved from http://jurnal.ugm.ac.id/ buletinpsikologi/article/view/7435.

Harrison, N. N. (2011). Assessing teacher and parent support as moderators in the relationship between black high school student's academic achievement and sosioeconomic status. (Doctoral dissertation). United States: UM Proquest LLC.

Hong, S., Yoo, S. K., You, S., \& Wu, C. C. (2010). The reciprocal relationship between parent involvement and mathematics achievement: Autoregressive cross-lagged modeling. The Journal of Experimental Education, 78(4). DOI: 10.1080/0022097090 3292926.

House, J. S. \& Kahn, R. L. (1985). Measure and concepts of social support. In Cohen, S. \& Syme, S. L (Eds), Social support and health health (pp. 83-108). Florida: Academic Press.

Johnson, K. A. (2000). The Peer Effect on Academic Achievement among Public Elementary School Students. Center for Data Analysis Report \#00-06 on Education. Retrieved from http://www.heritage.org/research/reports/2000/05/peer-effect-on-achievementamong-elementary-school-students

Ministry of Education and Culture \& Tempo. (2014). Analisis dan pemanfaatan hasil ujian nasional SMA sederajat tahun 2013-2014 [Analysis and usage of national examination results of senior high schools 2013/2014]. Jakarta, Indonesia: Kementerian Pendidikan dan Kebudayaan \& Tempo.

Keswara, R. (2013). Pembelajaran Matematika di Indonesia masuk peringkat rendah [Mathematical teaching in Indonesia categorized low level]. Sindonews. Retrieved from http://nasional.sindonews.com/read/2013/11/11/15/804091/pembelajaran-Matematika-diindonesia-masuk-peringkat-rendah

Kiamanesh. A. R. (2004). Factor affecting Iranian student's achievement in mathematics. First IEA International Research Conference. Retrieved from http://testieanl.ieadpc.org/fileadmin/user_upload/IRC/IRC_2004/Papers/IRC2004_Kiamanesh.pdf

Lee, E. V., Smith, J. B., Perry, T. E., \& Smylie, M. A. (1999). Social support, academic press, and student achievement: A view from the middle grades in Chicago. Chicago: The University of Chicago Consortium on Chicago School Research. Retrieved from https://ccsr.uchicago.edu/sites/default/files/publications/p0e01.pdf

Lefrancois, G. R. (2000). Psychology for teaching (10 th Edition). New York: Thomson Learning.

Lopez, E. J., Ehly, S., \& Garcia-Vazquez, E. (2002). Acculturation, social support, and academic achievement of Mexican and Mexican American high school students: An exploratory study. Psychology in the School, 39(3), 245-257. DOI: 10.1002/pits.10009

Malecki, C. K. \& Demaray, M. K. (2002). Measuring perceived social support: Development of the child and adolescent social support scale (CASS). Psychology in the School, 39(1), 1-18. DOI: 10.1002/pits.10004

Malecki, C. K. \& Demaray, M. K. (2003). What type of support do they need? Investigating student adjustment as related to emotional, informational, appraisal, and instrumental support. School Psychology Quarterly, 18(3), 231-252. DOI: 10.1521/scpq.18.3.231. 22576

Mitchell, S. N. \& DellaMattera, J. N. (2010). Teacher support and student's self efficacy. Journal of Contemporar Issues in Education, 5(2), 24-35. Retrieved from https://ejournals.library.ualberta.ca/index.php/JCIE/article/view/7497

Murayama, K., Pekrun, R., Lichtenfeld, S., \& Hofe, R. (2012). Predicting long-term growth in student's mathematics achievement: The unique contributions of motivation and cognitive strategies. Child Development, 84(4), 1475-1490. DOI: 10.1111/cdev.12036.

OECD (2012). PISA 2012 Results in Focus: What 15-year-olds know and what they can do with what they know. Retrieved from http://www.oecd.org/pisa/keyfindings/pisa-2012-results-overview.pdf

Park, K. (2004). Factors contributing to Korean student's high school achievement in mathematics. Retrieved from http://matrix.skku.ac. $\mathrm{kr} /$ For-ICME-11/ICME/cp5.pdf

Parsons, R. D., Hinson, S. L., \& Brown, D. S. (2001). Educational psychology a practioner-researcher model of teaching. USA: Wadsworth Thomson Learning.

Rustika, I. M. (2014). Faktor-faktor yang mempengaruhi prestasi akademik pada remaja [Factors affecting academic achievments in teenagers]. (Doctoral dissertation). Yogyakarta, Indonesia: Faculty of Psychology, Gadjah Mada University.

Sakiz, G., Pape, S. J., \& Hoy, A. W. (2011). Does perceived teacher affective support matter for middle school students in mathematcs classrroms? Journal of School Psychology, 50(2), 235-255. DOI:10.1016/j.jsp.2011.10.005.

Santrock, J. (2010). Life-span development (13'rd Edition). New York: Mcgraw-Hill.

Santrock, J. (2011). Educational psychology (5th Edition).. New York: McGraw-Hill.

Schunk, D.H. (2012). Learning theories an educational perspective (6 $6^{\text {th }}$ Edition). New Jersey: Pearson Prentice Hall.

Sembiring, R. K., Hadi, S., \& Dolk, M. (2008). Reforming mathematics learning in Indonesian classrooms through RME. ZDM Mathematics Education, 40(6), 927-939. DOI: 10.1007/s11858-008-0125-9

Shaffer, D. R. \& Kipp, K. (2010). Developmental psychology: Childhood and adolescence (9th Edition). USA: Wadsworth Cengage Learning.

Siegler, R. S., Duncan, G. J., Davis-Kean, P. E., Duckworth, K., Claessens, A., Engel, M., ... Chen, M. (2012). Early predictors of high school mathematics achievement. Psychological Science, 23(7), 691-697. 10.1177/0956797612440101. 
Snowman, J. \& McCown, R. (2012). Psychology applied to teaching (13'rd Edition). USA: Wadsworth Cengage Learning.

Sternberg, R. J. \& Williams, W. M. (2009). Educational psychology (2nd Edition). Boston, USA: Allyn \& Bacon.

Suryabrata, S. (2011). Psikologi pendidikan [Educational psychology]. Jakarta, Indonesia: Rajawali Press.

Syafaruddin, M. (2012). Hubungan antara dukungan orangtua dengan prestasi belajar siswa SMA Negeri 1 Keruak Kabupaten Lombok Timur [Relation between parental supports and student achievement in SMA Negeri 1 Keruak Kabupaten Lombok Timur]. Media Bina IImiah, 6(4), 25-32. Retrieved from http://www.Ipsdimataram.com/index.php?option=com_content\& view=article\&id=117: hubungan-antara-dukungan-orang-tua-dengan-prestasi-belajar-siswa-sma-negeri-1-keruak-kab-lombok-timur\&catid=37:2012\& Itemid $=63$

Tocci, C.M., \& Engelhard, G. (1991). Achievement, parental support, and gender differences in attitudes toward mathematics. The Journal of Educational Research, 84(5), 280-286. DOI: 10.1080/00220671.1991.10886028

Ulfah, K. (2012). Hubungan antara dukungan orangtua, dukungan sosial teman, dan harga diri dengan prestasi akademik siswa KMS pada jenjang Sekolah Menengah Pertama di kota Yogyakarta [Relationship between parental support, peer support; social support, and self-esteem with academic achievements in KMS students in junior high schools in Yogyakarta]. (M.A. thesis). Yogyakarta, Indonesia: Faculty of Psychology, Gadjah Mada University.

Varol, F., \& Farran, D.C. (2006). Early mathematical growth: How to support young children's mathematical development. Early Childhood Education Journal, 33(6), 381-387. DOI: 10.1007/s10643-006-0060-8

Wentzel, K. \& Caldwell, K. (1997). Friendships, peer acceptance, and group membership: relations to academic achievement in middle school. Child Development, 68(6), 1198-1209. DOI: 10.1111/j.1467-8624.1997.tb01994.x

Woolfolk, A. (2007). Educational psychology (10 ${ }^{\text {th }}$ Edition). Boston: Pearson Education. 